\title{
TOTAL PROTEIN ANALYSIS AND TRANSMISSION ELECTRON MICROSCOPY AS METHODS FOR DETECTION OF CLODINAFOP-PROPARGYL HERBICIDE RESISTANCE IN THE GREEN ALGA Scenedesmus quadricauda \\ Ahmed, S.A.*; G. I. A. Mohamed ${ }^{\star *}$ and S. M. El-Sagheer ${ }^{\star}$ Plant Protection Dept.* and Genetics Dept.**, Fac. of Agric., Assiut Univ., Egypt
}

\begin{abstract}
Green alga cultures of Scenedesmus quadricauda were treated with different concentrations of clodinafop-propargyl herbicide (0, 10.5 21, 42 and 84 ppm). Transmission electron microscopy and total protein analysis were applied to clarify the resistance of herbicide. Photos of longitudinal section in algal cell wall showed clear response to different concentrations of the herbicide. The response appeared as change in cell shape and increase in cell size, as well as thickness in the layers forming the cell wall which may indicate a type of resistance mechanism. Total protein analysis showed inducing or inhibition of the synthesis of some polypeptide fractions by herbicide treatments. These polypeptide fractions may have a role in resistance mechanism. These results encourage using green algal cell suspension of $S$. quadricauda for screening of herbicide resistance.

Keywords: Green alga, herbicide resistance, Scenedesmus quadricauda, total protein analysis, transmission electron microscopy, clodinafoppropargyl.
\end{abstract}

\section{INTRODUCTION}

Green algal cell suspensions are used in agrochemical research for screening herbicides (Ma et al., 2002). The use of herbicides is threatened by the emergence of resistant biotypes (Amanda et al., 2002) that considerably decreases the efficacy of herbicide treatments. With the increasing development of weed resistance to many popular selective herbicides, the need has arisen to diagnose herbicide resistant weeds as a first step in resistance management and monitoring their nature, distribution, and effective screening tests (Becki et al., 2000).

Herbicide resistance may occur as a result of one or more mechanisms including reduction in herbicide uptake or translocation, increased herbicide metabolism, sequestration of the herbicide or modified target site (Maneechote et al., 1994).

From the previous studies, (Fedtke, 1991) and (Mohamed et al., 2010) explained the observed resistance behavior in the green algae, Chlamydomonas reinhardtii and Scenedesmus quadricauda by the possible resistance mechanism of uptake, metabolism and lipid or amino acid composition. In addition to the role of metabolic detoxification in the resistance phenomenon and the importance of target site insensitivity, mutations in chloroplast genes such as acetyl-CoA carboxylase (ACCase) enables molecular tools such as allele-specific PCR assay to monitor resistance alleles in green algae (Chlorophyta) S. quadricauda. However, green alga $S$. quadricauda showed that the corresponding mutations is 
Ahmed, S. A. et al.

accompanied by other resistance mechanisms such as free amino acids content and cell number change (Mohamed et al., 2010).

The development of new cytological techniques, especially phase microscopy, cytochemical methods, and electron microscopy of thin sections has stimulated renewed investigations into the long controversial organization of blue-green algae (Ris and Singh, 1961). Susceptible and resistant cells were scanned and photographed using the scanning electron microscope to clarify the differences between resistant and susceptible cells (Ibrahim et al., 2009).

In this work, methods of total protein analysis and transmission electron microscopy were used to detect and confirm resistance mechanisms to the herbicides in green alga (Chlorophyta) S. quadricauda.

\section{MATERIALS AND METHODS}

\section{Culture conditions:}

Green alga (Chlorophyta) Scenedesmus quadricauda (strain Berb 614) was kindly supplied by Faculty of Science, Assiut University, Egypt. The medium for the algal growth was prepared according to Modified Bristol's Medium (MBM) (Wong, 2000). Alga was propagated photoautotrophically in a $500 \mathrm{ml}$ Erlenmeyer round flasks supplemented with compressed air (to prevent cells from clumping) and continuous illumination by cool-white fluorescence lamps giving approximately 3000 Lux. The trial was conducted at room temperature $\left(23 \pm 2^{\circ} \mathrm{C}\right)$.

\section{Herbicide treatments}

Clodinafop, aryloxyphenoxypropionate (APP) a selective post-emergence herbicide, was used in this study. The herbicide in wettable powder form was diluted with sterile distilled water and added into the sterile MBM in various concentrations. Cells were exposed to the herbicide concentrations: control $(0.0), 10.5,21,42$ and $84 \mathrm{ppm}$. Samples for transmission electron microscopy and total protein analysis were taken after 6 generations of exposure to the concentrations of $(0.0,10.5,21,42$ and $84 \mathrm{ppm})$.

\section{Longitudinal section in alga cell wall}

Samples $(10.5,21,42$ and $84 \mathrm{ppm})$ were taken in labeled test tubes and fixed in $5 \%$ glutheraldehyde for $24 \mathrm{hrs}$. The specimens were then washed in cacodylate buffer $(0.1 \mathrm{M}, \mathrm{pH} 7.2) 3-4$ times for $20 \mathrm{~min}$. at each time and then post fixed in $1 \%$ osmium tetroxide for 2 hrs. After repeated washing in cacodylate buffer ( $4 \times 20 \mathrm{~min}$.), by using ascending grades of ethyl alcohol up to $100 \%(30,50,70,80,90$ and $100 \% / 2 \mathrm{hrs})$ dehydration was done using gelatin capsule embedded in Epon 812. For polymerization, the embedded samples were kept in an incubator at $35^{\circ} \mathrm{C}$ for one day, at $45^{\circ} \mathrm{C}$ for another day and three days at $60^{\circ} \mathrm{C}$.

From prepared blocks, using LKB ultra microtome, semi thin sections in thickness of $0.5-1 \mu$ were prepared. The sections were stained by toluidine blue, examined by light microscope and photographed. Regions for preparation of ultra thin sections were oriented by Leica ultramicrotome. The ultrathin sections in thickness of 500-800 $\AA$ were made and fixed on copper 
grids $(200 \mu$ meshes). The ultrathin sections were then contrasted in uranyl acetate for $15 \mathrm{~min}$. and lead citrate for $5 \mathrm{~min}$. and examined by a transmission electron microscope (Jeol, CX11) in Electron Microscope Unit, Assiut University, Egypt.

\section{Protein extraction and purification}

Five samples of algal cultures were used including one control sample (untreated culture) and four clodinafop-propargyl treated samples at concentrations corresponding to 10.5, 21, 42 and $84 \mathrm{ppm}$.

The protein was extracted using modified method of Delye et al., (2002) as follows:

- Ten $\mathrm{ml}$ algal suspension were harvested by centrifugation at $5000 \mathrm{rpm}$ for 5 min. then the supernatant was discarded.

- The pellets were ground to fine powder in liquid nitrogen and homogenized in 3 volumes $(\mathrm{w} / \mathrm{v})$ of extraction buffer $(50 \mathrm{mM}$ Tris $-\mathrm{HCl}, \mathrm{pH} 8,5 \mathrm{mM}$ dithiothereitol, $1 \mathrm{mM}$ EDTA).

- The samples were filtered through eight layers of filter paper and centrifuged at $5000 \mathrm{rpm}$ for $15 \mathrm{~min}$.

- The supernatant was brought to $80 \%$ saturation with solid ammonium sulfate $\left(\left(\mathrm{NH}_{4}\right)_{2} \mathrm{SO}_{4}\right)$ and centrifuged at $5000 \mathrm{rpm}$ for $15 \mathrm{~min}$.

- The pellets were resuspended in a small volume of saturated $\left(\mathrm{NH}_{4}\right)_{2} \mathrm{SO}_{4}$ and stored at $-20^{\circ} \mathrm{C}$.

- The precipitated protein was centrifuged at $5000 \mathrm{rpm}$ for $10 \mathrm{~min}$. and dissolved in 2 volumes of phosphate-buffered saline buffer containing $5 \mathrm{mM}$ dithiothereitol then kept at $4^{\circ} \mathrm{C}$.

\section{Protein electrophoresis}

Total protein analyses using SDS-PAGE according to Laemmli (1970) were used and protein molecular mass was determined using Gel-Pro Analyzer package (Media Cybernetica 1993-97). Control sample (untreated culture) and other four samples of treated cultures by different herbicide concentrations $(10.5,21,42$ and $84 \mathrm{ppm})$ were used in total protein analysis.

The proteins of the ACCase peaks were separated by SDS-PAGE on 4 to $15 \%$ gradient fast gel. Proteins were then transferred to Immobilon-P membranes using $10 \mathrm{mM}$ CAPS (3-cyclohexylamine-1-propane sulfonic acid), $\mathrm{pH} 11$ and $50 \mathrm{mM} \mathrm{NaCl}$ as the transfer buffer. Biotinylated proteins were probed using avidin-alkaline phosphatase (De Prado et al., 2000).

\section{RESULTS AND DISCUSSION}

\section{Transmission electron microscopy}

Structure control of the cell wall of $S$. quadricauda consists of three layers: the inner cellulosic layer (CEL) which delimits individual cells; the outer pectic layer (PL) which binds the cells of the coenobium together; and a thin middle layer or trilaminar layer (TRL), bounded by membranes on either side. Comparison was made between conrtol cells of $S$. quadricauda and cells exposed to different clodinafop-propargyl concentrations (10.5, 21, 42 and $84 \mathrm{ppm})$.

Transmission electron micrographs of $S$. quadricauda control cell (Fig. 1) show that the cell wall consists of the three layers previously described. The outer pectic layer $(\mathrm{PL})$ and the trilaminar middle layer $(T R L)$ are thick, while 
Ahmed, S. A. et al.

the inner cellulose layer (CEL) is thinness. Morphological analysis of algae in regulatory testing is known to be strongly recommended and could be extended beyond the Scenedesmaceae, as for example in Chlamydomonas the herbicide paraquat also caused morphological changes (Lurling, 2006) and (Hassanien, 2006) found significant increase in cell volume and wall thickness in ametyren selected biotype of $S$. vacuolatus.

At $10.5 \mathrm{ppm}$ herbicide concentration (Fig. 2), the cell showed large thickness in the outer pectic layer $(P L)$ and trilaminar layer $(T R L)$, while the inner cellulosic layer (CEL) still thinness. In addition, change in shape and increase in the cell size was observed in all concentrations of herbicide treated cell, compared with control cell. At $21 \mathrm{ppm}$ herbicide concentration (Fig. 3) the cell showed large thickness in the three layers especially in the inner cellulose layer (CEL) that was very thick which reflects the cell response to the herbicide dosage. This may suggest a type of resistance. At $42 \mathrm{ppm}$ concentration (Fig. 4) the cell showed large thickness in the outer pectic layer $(\mathrm{PL})$, while the middle layer trilaminar layer $(\mathrm{TRL})$ and the inner cellulose layer (CEL) were thinness.

In (Fig. 5) at 84 ppm concentration, the cell showed very large thickness in all three layers, compared with control. In atrazine resistant Conyza canadensis, the thylakoid membrane lipids contained a lower amount of polar lipid and the fatty acid content exhibited a higher degree of unsaturation (Szigeti and Lehoczki, 2003). The high variability in sensitivity of different algal species to the same chemical substance can be explained by the morphology, cytology, physiology and genetics of the organisms (RojiEkova-Padrtova and MarGlek, 1999). The bioassay and biochemical data confirmed the role of herbicide metabolic degradation as a main mechanism of resistance toward herbicides. In addition, surface area of resistant cell was about four times greater than susceptible cell (Ibrahim et al., 2009).

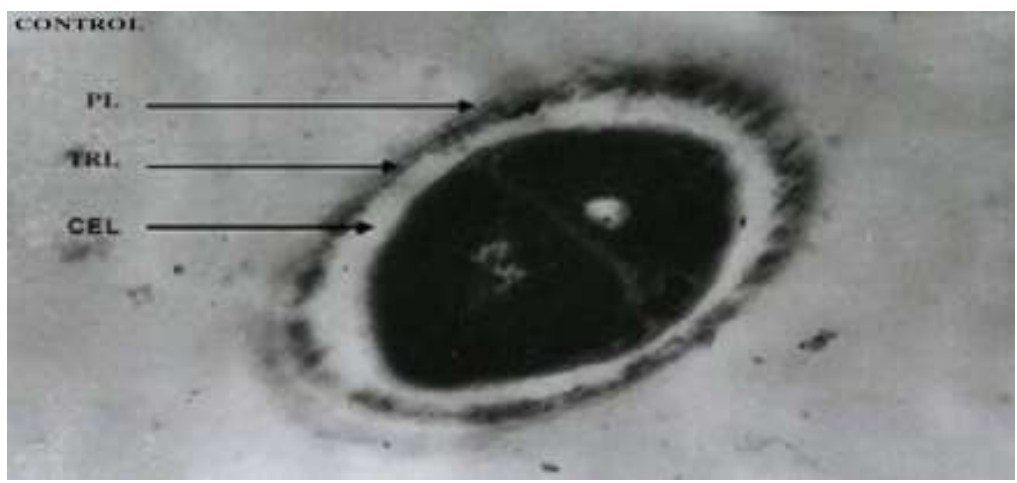

Fig. 1: Longitudinal section of control cell of Scenedesmus quadricauda after the sixth generation showing cellulosic layer (CEL), trilaminar layer (TRL) and pectic layer (PL). Magnification 14,000X. 


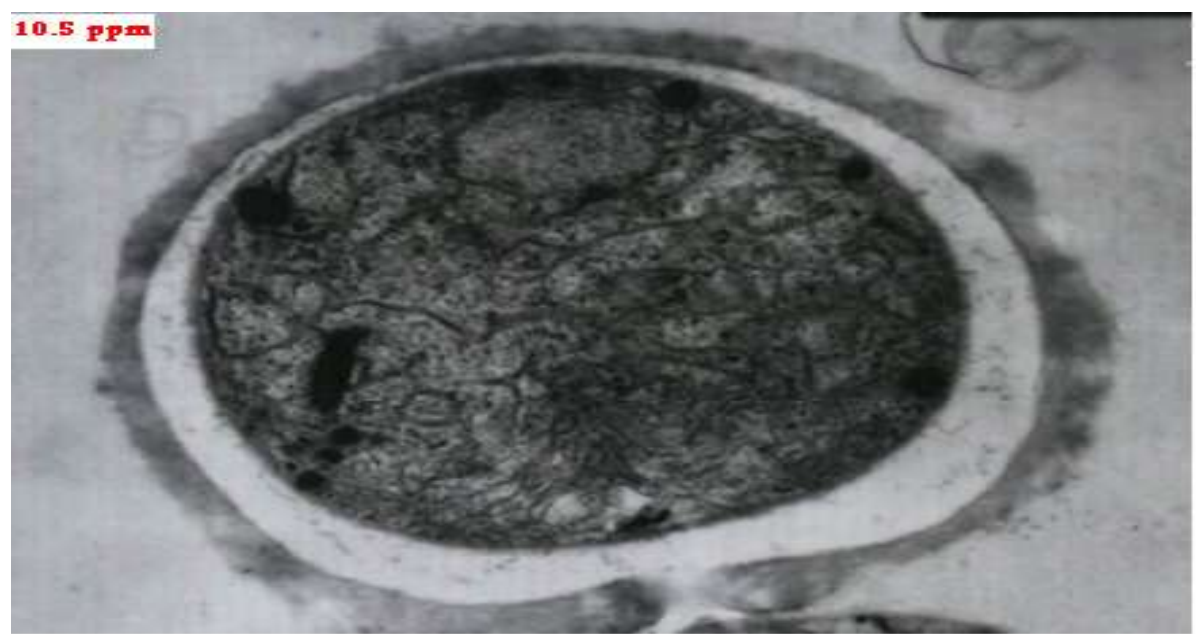

Fig. 2: Longitudinal section of $S$. quadricauda cell, after the sixth gneration of exposing to clodinafop-propargyl at $10.5 \mathrm{ppm}$. This photo shows cellulosic layer (CEL), trilaminar layer (TRL) and pectic layer (PL). Magnification 14,000X.

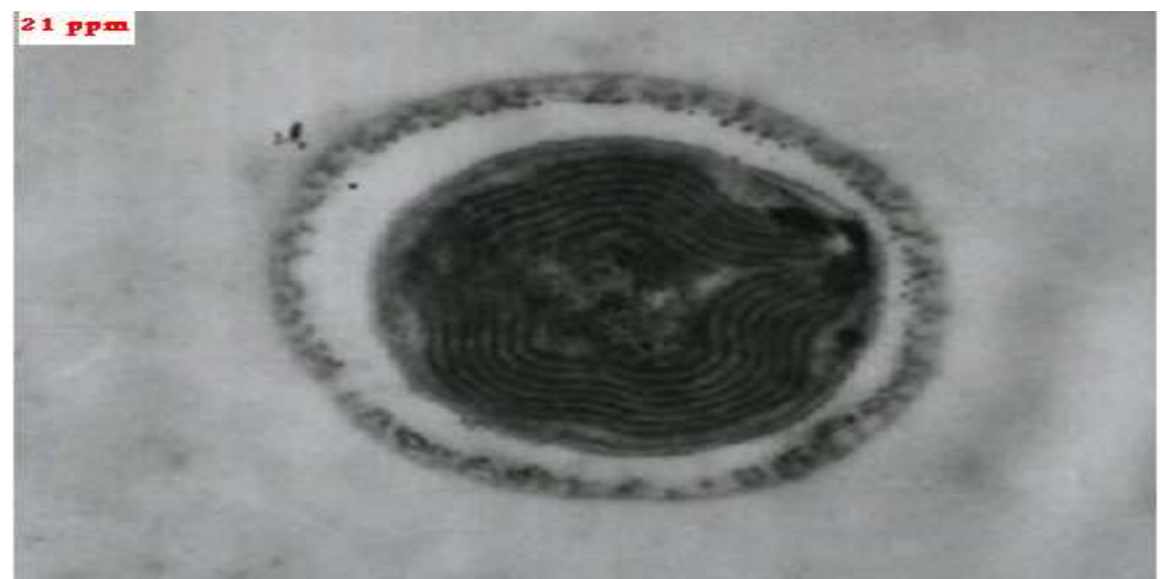

Fig. 3: Longitudinal section of $S$. quadricauda cell, after sixth generations of selection with clodinafop-propargyl at $21 \mathrm{ppm}$ showing cellulosic layer (CEL), trilaminar layer (TRL) and pectic layer (PL). Magnification 14,000X. 
Ahmed, S. A. et al.

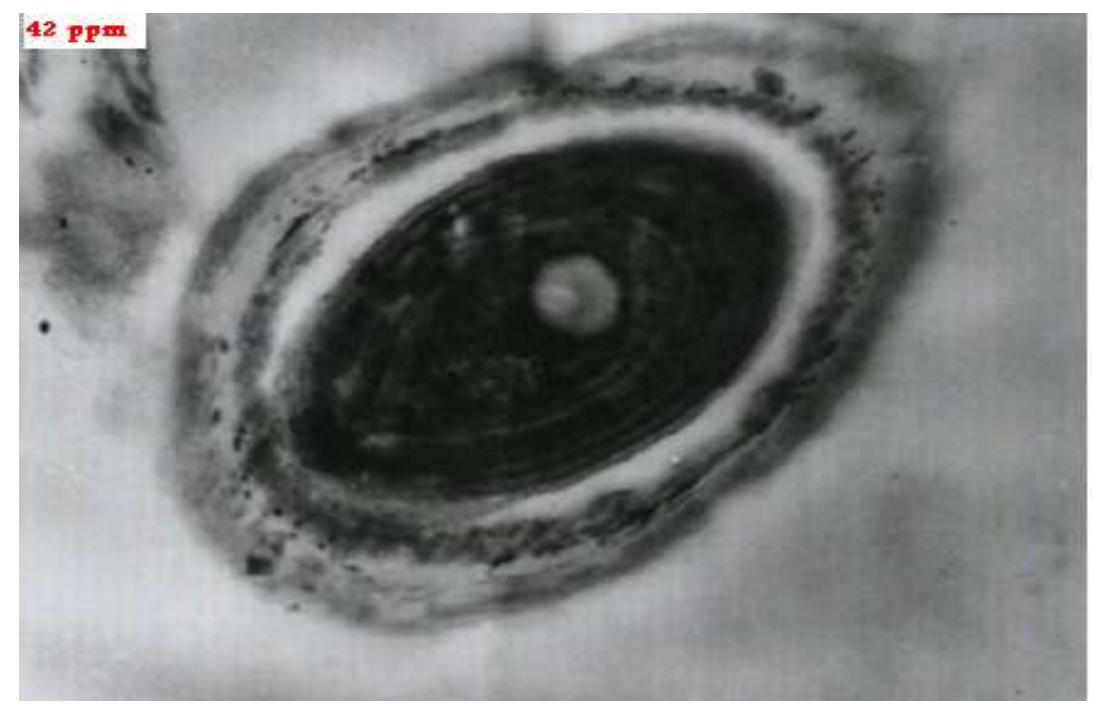

Fig. 4: Longitudinal section of $S$. quadricauda cell, after sixth generations of selection with clodinafop-propargyl at $42 \mathrm{ppm}$ showing cellulosic layer (CEL), trilaminar layer (TRL) and pectic layer (PL). Magnification 14,000X.

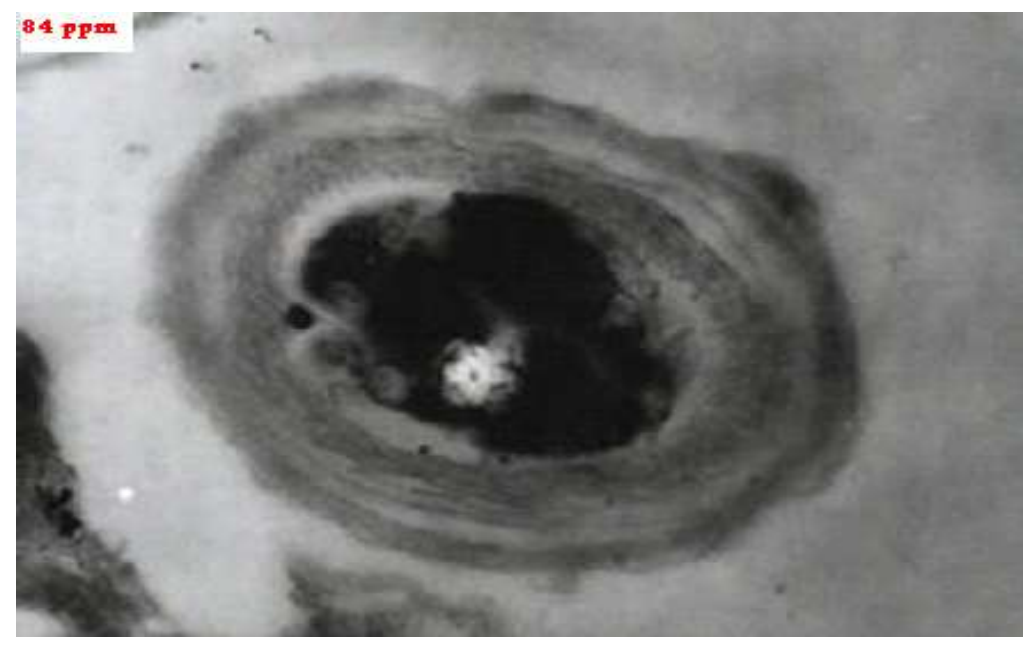

Fig. 5: Longitudinal section of $S$. quadricauda cell, after sixth generations of selection with clodinafop-propargyl at $84 \mathrm{ppm}$ showing cellulosic layer (CEL), trilaminar layer (TRL) and pectic layer (PL). Magnification14,000X. 
Total protein analysis by polyacrylamide gel electrophoresis (SDSPAGE)

Total protein analysis was performed for five samples, i.e., control and four treated samples with 10.5, 21, 42 and 84 ppm herbicide concentrations. Protein

of purification fractions separated by SDS-PAGE (Fig. 6) and analysis of the molecular weight in Kda (Table 1) showed that the total number of protein fractions produced by all samples were 56 fragments. The number of protein fractions per sample varied between 10 to 12, with an average of eleven fractions per sample. These polypeptide fractions have a size ranged from about 9 to $110 \mathrm{Kda}$.

A total number of 56 fractions were shown with 40 polypeptide fractions being monomorphic (shared by all examined treated and untreated samples), and the other 16 polypeptide fractions were polymorphic (exist in some treated or untreated samples and not exist in the others). Polypeptide fractions with 72.17 and $19.81 \mathrm{kda}$ were present only in control sample (untreated) and absent in all treated samples suggesting that the synthesis of these polypeptide may be inhibited by herbicide treatment. This result agreed with that found in algae and cyanobacteria by (Kotrikla et al., 1999). However, the protein content in grains of greengram was found to be severely affected by the highest dose rates of atrazine and isoproturon, suggesting that the enzymes and other functional proteins are one of the target sites of herbicide toxicity, which subsequently leads to alteration in the protein metabolism of grains (Khan et al., 2006).

On the other hand, the polypeptide fractions with about 45, 49, 50 and 14 Kda were found to be present only in the treated samples and absent in the untreated ones, suggesting that the herbicide treatments catalyze the synthesis of these polypeptides in the treated algal cells and may had a role in the resistance mechanism of algae against herbicide treatments.

These results are congruent with that reported by (Fayez and Kristen, 1996; Fayez, 2000) who reported modulated metabolic activities of the cell under stress conditions. Polypeptide fraction with 25.36 kda presented only in treated sample by $21 \mathrm{ppm}$ herbicide concentration and absent in all other treated samples and the control. This result might be related with large thickness found in the inner cellulose layer (CEL) that treated by this herbicide concentration. Also, polypeptide fractions with 11.7 and $13.19 \mathrm{kda}$ presented only in treated samples with 10.5 and $21 \mathrm{ppm}$ herbicide concentration, respectively, and control sample but absent in the other treated ones. These results suggest that the synthesis of these polypeptides may be induced as a cell response to the herbicide treatments, as well as, it may explain the thickness in the three cell layers found in the herbicide treatments.

Using diuron herbicide on Chlorella vulgaris by (Fayez and Abd-Elfattah, 2007), protein and carbohydrate contents (total and soluble) of algae decreased significantly $(\mathrm{P}<0.01)$ with increasing herbicide doses. However calculation of the concentration of protein and carbohydrate on the basis of dry weight showed an increase in their contents with increasing herbicide 
Ahmed, S. A. et al.

doses. The soluble protein content in control and at lowest dose $(0.1 \mu \mathrm{m})$ was 23 and $35 \mathrm{mg} \mathrm{g} / 1$ dry weight, respectively.

In our study, thickness in the layers forming the cell wall may suggest a type of resistance mechanism. In addition, herbicide treatment modulated metabolic activities of the cell as found in inducing or inhibiting synthesis of polypeptide fractions which may have a role in resistance mechanism. Finally, it is suggested that green algal cell suspensions of $S$. quadricauda could be used in agrochemical research for screening herbicide resistance.

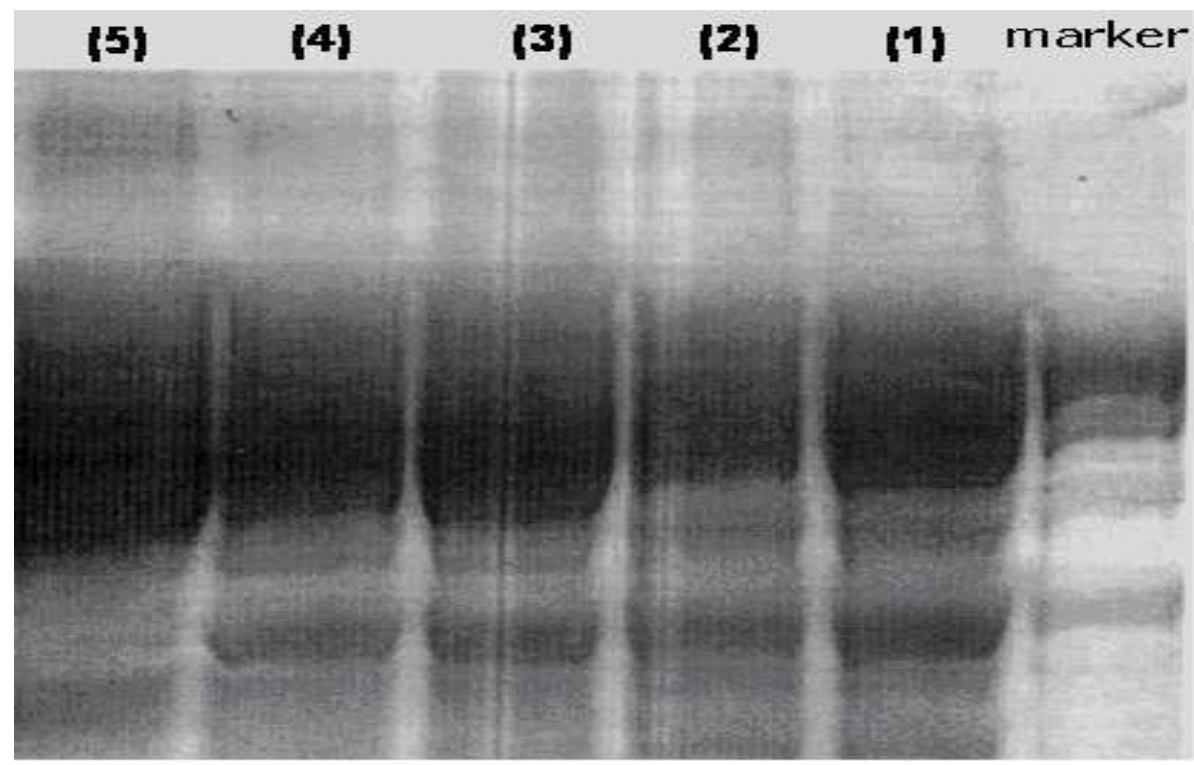

Fig. 6: Total protein of purification fractions separated by SDS-PAGE Scenedesmus quadricauda algal samples with different herbicide concentrations. From right: marker then samples 1= control, $2=84 \mathrm{ppm}, 3=42 \mathrm{ppm}, 4=21 \mathrm{ppm}$ and $5=10.5 \mathrm{ppm}$, respectively. 
Table 1: Total protein fractions separated by SDS-PAGE and the molecular weight in Kda of $S$. quadricauda algal samples with different herbicide concentrations.

\begin{tabular}{|c|c|c|c|c|c|c|}
\hline Lanes & Marker & Control & $\mathbf{8 4}$ ppm & $\mathbf{4 2}$ ppm & $\mathbf{2 1}$ ppm & $\mathbf{1 0 . 5}$ ppm \\
\hline $\begin{array}{c}\text { Protein } \\
\text { fractions }\end{array}$ & \multicolumn{5}{|c|}{ Molecular weight in Kda } \\
\hline$r_{1}$ & 200 & & & & & \\
\hline$r_{2}$ & 150 & & & & & \\
\hline$r_{3}$ & 120 & & & & & \\
\hline$r_{4}$ & & 110.144 & 117.1403 & 112.5174 & 111.3494 & 118.933 \\
\hline$r_{5}$ & 100 & 91.224 & 94.0479 & 90.1709 & 96.9494 & 96.8888 \\
\hline$r_{6}$ & 85 & 86.601 & 84.1472 & 84.6427 & 85.1317 & 83.8803 \\
\hline$r_{7}$ & & 72.174 & & & & \\
\hline$r_{8}$ & 70 & 69.912 & 65.7467 & 68.5829 & 73.8018 & 70.0168 \\
\hline$r_{9}$ & 60 & & & & & \\
\hline$r_{10}$ & 50 & & 45.4994 & 50.1025 & 45.9345 & 49.2109 \\
\hline$r_{11}$ & & 31.264 & 27.4392 & 28.5599 & 35.7093 & 45.5937 \\
\hline$r_{12}$ & 30 & 29.648 & 26.2218 & 28.6184 & 28.0879 & 29.2133 \\
\hline$r_{13}$ & 25 & & & & 25.3594 & \\
\hline$r_{14}$ & & 22.828 & 21.367 & 21.378 & 21.7274 & 24.718 \\
\hline$r_{15}$ & 20 & 19.809 & & & & \\
\hline$r_{16}$ & & 16.18 & 16.028 & 17.995 & 16.4164 & 16.0126 \\
\hline$r_{17}$ & 15 & & 14.01 & 14.0722 & 14.1657 & 14.26 \\
\hline$r_{18}$ & & 11.024 & & & 13.194 & 11.729 \\
\hline$r_{19}$ & 10 & 9.144 & & 10.912 & & \\
\hline
\end{tabular}

\section{REFERENCES}

Amanda, C.B.; Stephen R.M.; Zoe, A.W. and Linda M.F. (2002). An isoleucine to leucine substitution in the ACCase of Alopecurus myosuroides (black-grass) is associated with resistance to the herbicide sethoxydim. Pesticide Biochem. and Physiol. 72: 160-168.

Beckie, H.J.; Heap, I.M.; Smeda, R.J. and Hall, L.M. (2000). Screening for herbicide resistance in weeds. Weed Technol. 14: 428-445.

De Prado, R.; Gonza I.J.; Mene'ndez, J.; Gasquez, J.; Gronwald, J.W. and Gime'nez-Espinosa, R. (2000). Resistance to acetyl CoA carboxylaseinhibiting herbicides in Lolium multiflorum. Weed Sci. 48:311-318.

Delye C.; Mate'jicek A. and Gasquez J. (2002). PCR-based detection of resistance to acetyl-CoA carboxylase-inhibiting herbicides in blackgrass (Alopecurus myosuroides Huds) and ryegrass (Lolium rigidum Gaud). Pest Manage. Sci. 58: 474-478. 
Fayez, K.A. and Kristen, U. (1996). The influence of herbicides on the growth and proline content of primary roots and on the ultra structure of root caps. Environ. Exp. Bot. 36: 71-81.

Fayez, K.A. and Zeinab, Abd-Elfattah (2007). Alteration in growth and physiological activities in Chlorella vulgaris under the effect of photosynthetic inhibitor diuron. Intern. J. Agri. and Biol. 9: 631-634.

Fayez, K.A. (2000). Action of photosynthetic diuron herbicide on cell organelles and biochemical constituents of the leaves of two soybean cultivars. Pestic. Biochem. Physiol. 66: 105-115.

Fedtke, C. (1991). Mode of action studies with mefenacet. Pesticide Sci. 33 : $421-426$.

Hassanein, A.M.A. (2006). Studies on Certain Herbicides Using High Performance Liquid Chromatography (HPLC) with Special Reference to the Resistance Phenomenon. Ph.D. thesis, Fac. Agri., Dept. Plant Protec., Minia Univ: pp.286.

Ibrahim, S.A. ;Tantawy, M.M.; Seleim, Z.M.; Al-Marsafy, H.T.A. and Hassanein, A.M.A. (2009). Metabolic detoxification as a viable mechanism for triazine herbicide resistance in ametryn resistant biotype of the fresh water chlorophyte, Scenedesmus vacuolatus. Sci. Res. and Essay: 4: 1331-1341.

Khan, M.S; Chaudhry, P.; Wani, P.A. and Zaidi, A. (2006). Biotoxic effects of the herbicides on growth, seed yield and grain protein of greengram. J. Appl. Sci. Environ. Mgt. 10:141-146.

Kotrikla, A.; Gatidou; G. and Lekkas, T.D. (1999). Toxic effects of atrazine, deethyl-atrazine, deisopropyl-atrazine and metolachlor on Chlorella fusca var-fusca. Global Nest: the Int. J. 1: 39-45.

Laemmli, U.K. (1970). Cleavage of structural proteins during the assembly of the head of bacteriophage T4. Nature. 227: 680-685.

Lurling, M. (2006). Effects of a surfactant (FFD-6) on Scenedesmus morphology and growth under different nutrient conditions. Chemosphere 62: 1351-1358

Ma, J.; Xu, L. and Wang, S. (2002). A quick simple and accurate method of screening herbicide activity using green algae cell suspension cultures. Weed Science 50: 555-559.

Maneechote, C.; Holtum, J.A.M.; Preston, C. and Powles, S.B. (1994). Resistant acteyl-CoA carboxylase is a mechanism of herbicide resistance in a biotype of Avena sterilis ssp. ludoviciana. Plant Cell Physiol. 35:627-635.

Mohamed, G.I.A.; Ahmed S.A. and El-Sagheer, S.M. (2010). Molecular basis of resistance to Clodinafop-propargyl, and Acetyl-CoA carboxylase inhibiting herbicide, in green algae Scenedesmus quadricauda. J. Plant Prot. and Path., Mansoura Univ. 1: 265-274.

Ris, H. and Singh, R.N. (1961). Electron microscope studies on blue-green algae. J. Biophys. and Biochem. Cytology 9: 63-80.

RojiEkova, P.R. and MarGlek, B. (1999). Selection and sensitivity comparisons of algal species for toxicity testing. Chemosphere. 38: 3329-3338. 
Szigeti, Z. and Lehoczki E. (2003). A review of physiological and biochemical aspects of resistance to atrazine and paraquat in Hungarian weeds. Pest Manage. Sci. 59: 451-458.

Wong, P.K. (2000). Effects of 2,4-D, glyphosate and paraquat on growth, photosynthesis and chlorophyll a synthesis of Scenedesmus quadricauda Berb 614. Chemosphere 41: 177-182.

تحليل البروتين الكلى وتقتية قطاعات الميكروسكوب الإكترونس كطرق للكشف عن المن

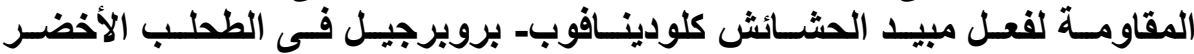
سيندسمس كوادريكودا

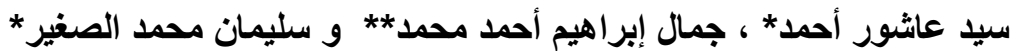
قسم وقاية النبات* وقسم الوراثة** ـ كلية الزراعة - جامعة أسيوط

عوملت مز ارع من الطحلب الأخضر سيندسمس كو ادريكودا بتركيز ات مختلفة من مبيد الحشائش

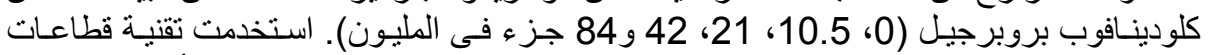

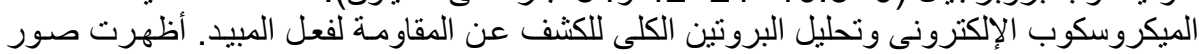

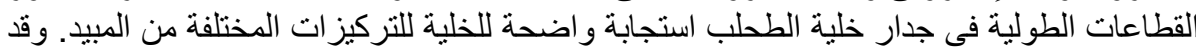

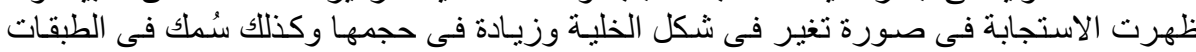

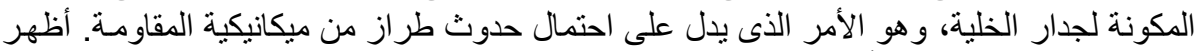

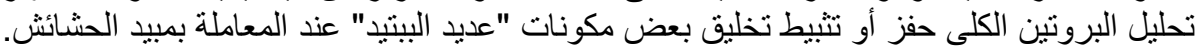

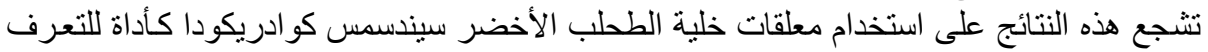
على المقاومة لفعل المبيد.

كلمات مفتاحية: الطحالب الخضر اء، المقاومة لفعل مبيدات الحشائش، سيندسمس كو ادريكودا، تحليل البروتين الكلى، قطاعات الميكروسكوب الإلكترونى، كلودينافوبـ بروبر الفيرجيل.

كلية الزراعة - جامعة المنصورة كلية الزراعة - جامعة اسيوط
قام بتحكيم البحث

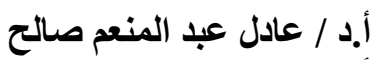
أ.د / عفت محمد محمود الفراش عل عال 